ポリチレン球晶の変形举動について

\author{
福井大学工学部 \\ 片阊紘三・高橋利祜 \\ 过本石堆
}

\title{
THE DEFORMATION BEHAVIOR OF POLYETHYLENE SPHERULITE
}

By Közō Kataoka, Toshisada Takahashi and Ishio Tsujimoto

(Faculty of Engineering, Fukui University, Fukui City, Fukui Prefecture, Japan)

The deformation behavior of polyethylene spherulite composed of spherical shells (extinction bands) was studied by polarized microscope. The spherulitic films were drawn with various ratios at $20^{\circ} \mathrm{C}$ and $100^{\circ} \mathrm{C}$, and the elongation ratios of each shell were evaluated.

The results obtained are as follows;

(1) The elongation ratio of the outermost shell, being the same as that of spherulite, is less than that of the sample. This indicates that the relative motion occurs between spherulites. The deviation from affine deformation is less for the hot drawn film than for the cold drawn film.

(2) The thickness of each elemental shell is almost uniform for the homogeneously deformed two-dimensional spherulite. Consequently the elongation ratios of outer shells are less than that of inner shells.

(3) Similarly a spherical shell in three-dimensional spherulite deform to an ellipsoidal shell, though the thickness of an elemental shell is not uniform. The crystal lamellae constituting these deformed shells must be disrupted to fullfil the geometric requirement.

(4) Deformation modes within a three-dimensional spherulite, which are generally deviated from affine deformation, depend on elongation ratios and deformation temperatures.

(Received December 16, 1971)

\section{1. 緒論}

球晶の変形過程を解明与ることは土業的にも基礎的に も重要な課題であり，結晶括よび非結晶部の配向過程， 形態変化なとについて多くの研究がなされているいーフ。

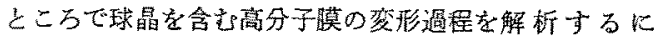

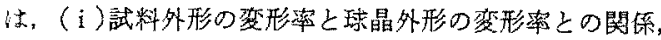

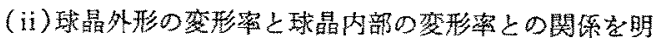
らがすることが必要である。（i）にいては3次元球 晶上り構成されているフィルムの場合，体筧一定のフフ

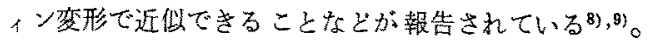
李た（ii）関しては，2次元球晶について子 3 次元球晶 についても㳬性的な観察結果が報告されて和り，それぞ

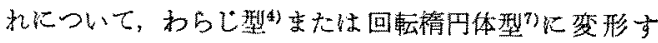
ることなとが見出されている程度である。したがって球 晶内部の変形様式については去不明な点が多い。

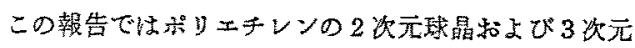

球晶を含さ膜を試粼として，1㑲延伸によるネッキング

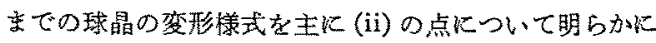

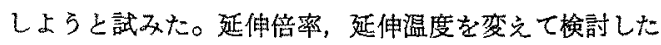
$と こ る$, 球晶の変形様试性球晶の状態（2次元球晶加 3 次元球晶が，延伸倍率，延伸温度に依存してかなり異 なることなどが見出されだ。な机压繀変形の場合につい ても娭討した。以下Kその結果を報告する。

\section{2. 実 験 方 法}

\section{$2 \cdot 1$ 試料作成}

ポりエチレン (ハイゼックス 5000\$) 安原試料とし

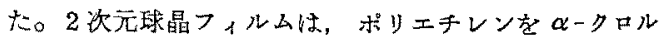
ナフタンリ的溶解し(約 $150^{\circ} \mathrm{C}$ ), 同温度で溶媒を蒸発 させた後空温息で俆冷した。フィルムの愿さは約 $30 \mu$, 球晶の直径性約 $0.2 \mathrm{~mm}$ で苛った。3次元球晶フィル

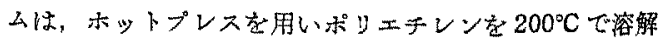
した啳室温まで狳烚して得た。フィルムの厚さは約 0.3 


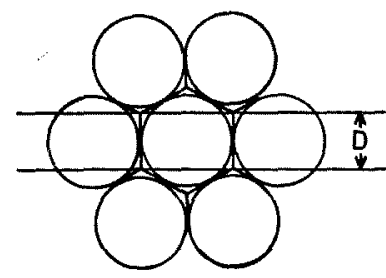

UNDRAWN SPHERULITE

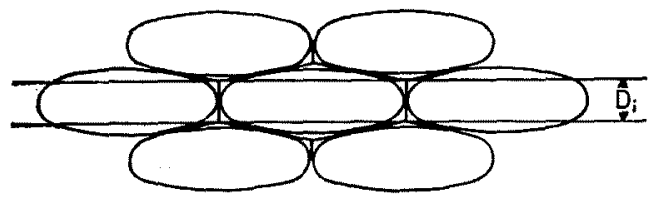

DRAWN SPHERULITE

Fig. 1. Schematic representation of the threedimensional spherulites. (Draw direction horizontal)
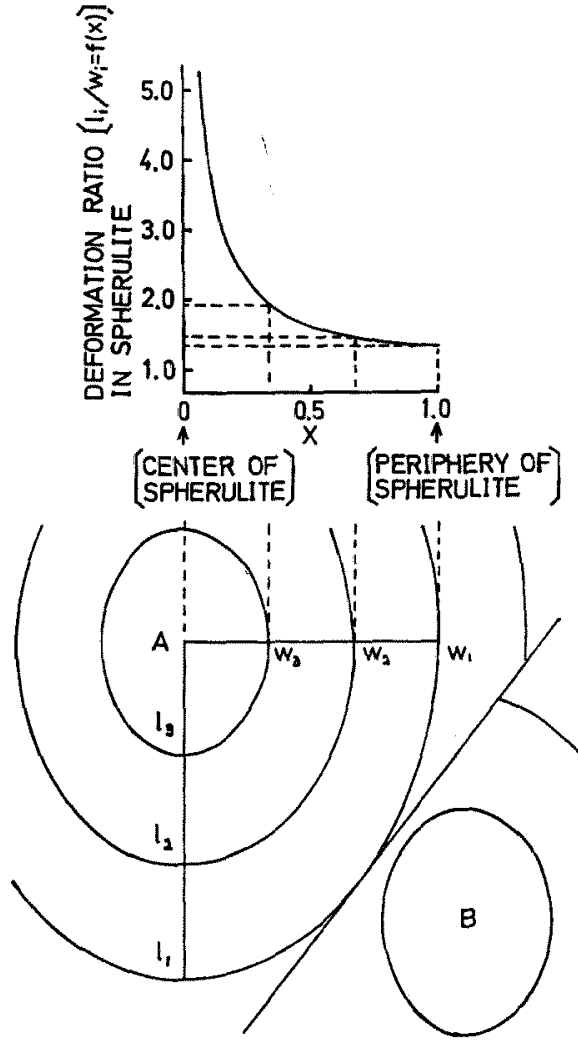

Fig. 2. Schematic representation with respect to a method of measurement of the deformation ratio within a spherulite. $\mathrm{mm}$ ，球晶の直佳恃約 $40 \mu$ であった。

\section{$2 \cdot 2$ 延伸方法および試料外形の縱横の変形比}

2 次元执よび 3 次元球晶を含むポリエチンンフィルム を長さ $40 \mathrm{~mm}$ ，幅 $8 \mathrm{~mm}$ 飞切り出し手的延伸機を用い て延伸した。延伸の際の有効長は $10 \mathrm{~mm}$ とし，10\%! $\min$ の延伸速度で温度 $20^{\circ} \mathrm{C}$ (空気中) 拈上び $100^{\circ} \mathrm{C}$ (沸 滕水中）で延伸した。以下の変形比の測定は延伸後 1 日 室温で放置してから行なった。

試料外形の变形率は約 $1 \mathrm{~mm}$ 間隔につ讨た印の変化 に上り延伸方向と平行特よび垂直方向に打いて测定し t。年れでれの変形率の此 $l / l_{0} / w / w_{0}$ を「变形比」とし た（未延伸時の長さを $l_{0}$, 幅を $w_{0}$ とした）。

\section{$2 \cdot 3$ 球晶の維横の変形比の測定方法}

3次元球晶よりなるフィルムの延伸方向に平行な断面 をモデル的に示したのが Fig.1で苛る。試料はフィルム 面儿直角儿，ま大延伸方向に平行にフリーハンドで安全 カミソリで切り，愿さをマイクロメータで測定し，10 前後の試料で釦鏡試料とした。この祭，厚さにむらの亦 るよらな試料は除いた。これ老観察する際，偏半頭微鏡 下でと゚ントを上下させても球晶の垷界が移動して隣接球 晶の境界と重なり合わないような球晶を選び。最大直径 のところにピントを合わせて写真撮影し，これについて 变形比を求めた。。の場合 Fig. 1 の $D_{t}$ の筑团内の断面

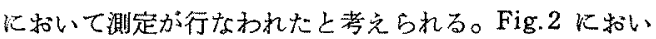
て変形されて梢円形之なった球晶の中心を $x=0$ ，短軸 の半径方向を横軸にとり，環状構造のリングが磷接球晶 とぶのかることなく完結されたリングとして認められる 殸を最外殸とし $x=1$ とした。球晶のたて横の变形比々 はこの最外殼についての長軸之短軸の長さの比を $L / W$ とする。球晶内部炕おるてれぞれの款の $l_{l} / w_{l}$ を求め， これを球晶内部のたて横の变形比とした（以下単に変形 比とい5)。一般飞 $l_{i} / w_{i}=f(x)(0<x \leq 1)$ は $x$ Kよ。 て異なるので，これをFig.2のよらに $x$ に対してプロッ トLた。

\section{3. 結果と考察}

球晶を含む高分子フィルムの変形過程を解明するには 緒論で述べたよちな(i)，(ii)の点が問題となる。以下 この点汇関してわれわれの得た結果について述べる。

\section{1 試料外形の変形比と球晶外形の変形比}

$3 \cdot 1 \cdot 12$ 次元球晶

延伸の際，球晶間怙よび球晶内に虾いて，ネッキング を伴う不均一な変形が起こり試料外形の変形比を゙評価す ることはできなかった。

$3 \cdot 1.2 \quad 3$ 次元球晶

Fig. 3 誥試料外形々球晶外形の延伸方向之，穴机に重 


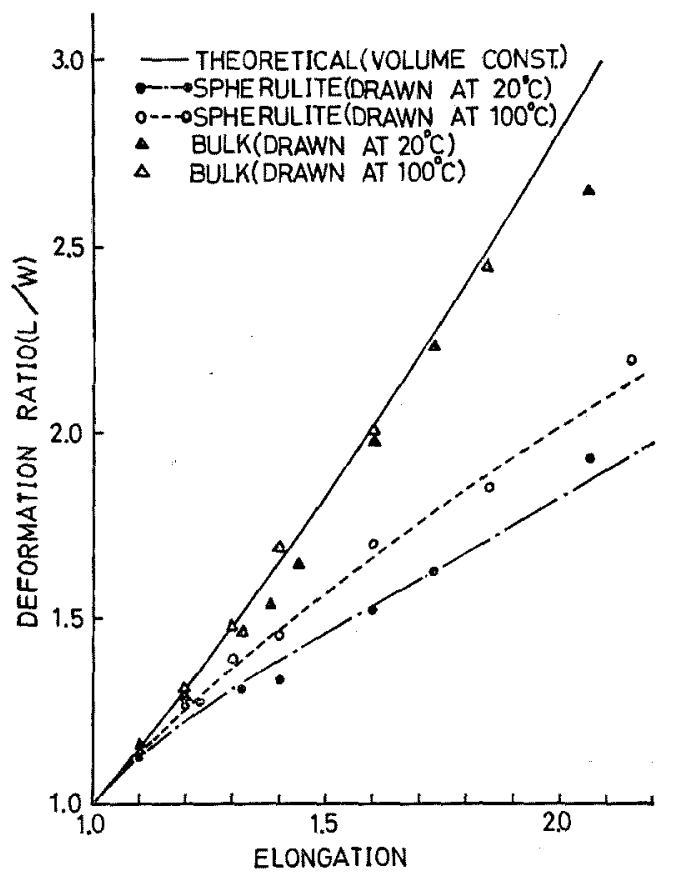

Fig. 3. Relations of the deformation ratio between bulk and periphery of spherulite in elongation.

直方向の大きさの此 $(L / W)$ の実測傅，捄よび体積一定 とした場合の $L / W$ の計算値 (実線) を延伸率に対して プロットしたもので方る。試料外形の $L / W$ の值は，体 㺓一定上仮定した時の計算值汇添涪一致しているが，球

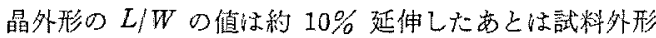
の $L / W$ の值上り小となっていることがわかる。この場 合，明らか炍球晶の变形比怯試料の变形比上り小で市 り，アフィン変換の仮定は成立していないことになる。 これ永晶間炕ずれが起こっていることによるものと考 克られる。この㑯向は低温で趆伸した場合の汪らが大き い。これは低温飞拮る変形の場合の涪らが，球晶境界 に怙汁る応力集中が起こりやすいことによる。

\section{$3 \cdot 2$ 变形樣式の評価方法}

Wilchinsky' が述べているように，球晶の変形梯式に は形式的以相似型のものと多重殼型のものが考克られ る。Fig.4. (a) は変形前の同心多重殼からなる球晶を示 す。これが変形する場合，内殻が最外殻之相似に変形す る場合を相似型変形 (Fig.4. (b))，球殼の厚さを一定に 保ちながら变形する場合を多重款型変形 (Fig.4(c)) と 称している。

球晶の変形㥞式を表わすのに，楕円形となった殼の長 軸と短軸の此（変形此 $l / w$ ) で示すことにする。椙似型
樑形の場合，各殼は相似であるから变形比 $(l / w)$ の值は 球晶内部のどの部分でも一定である。一方多重凯型变形 の場合飞は，殸間距離が一定といら条件から短軸方向を $x$ (球晶の中心を $x=0$ ，最外殼を $x=1.0$ とする）とし， $x$ 軸上の任意の点 $x_{i}$ とすると， $x_{i}$ と $x_{i}$ を含む款の 長軸との比 $\left(l_{l} / w_{i}\right)$ は内㲄になる汪ど大をなり， $l_{i} / w_{i}$ 灾 球晶の半経 $(x)$ 代対してプロットすると双曲線となる。 そこで球晶の変形様式を次式で表わす。

$l_{i} / w_{i}=f(x)=(L / W-1)(P+1) /(x+P)+1$

ここで $L / W$ は球晶最外豰の長軸と短軸の長さの比 (球晶の変形比)，Pは変形様式老表わすパラメータであ ろ。 $P=0$ のとき $f(x)$ は $x=1.0$ で $L / W$ の值をとる 双曲線となり，これは多重壳型变形を表わす。 $P=\infty$ の とき $f(x)$ は $0<x \leq 1$ 飞括いて常に $L / W$ の值をとり,

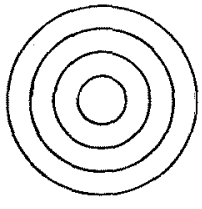

(a)

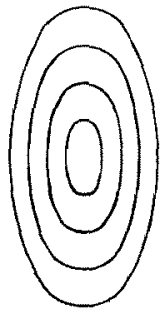

(b)

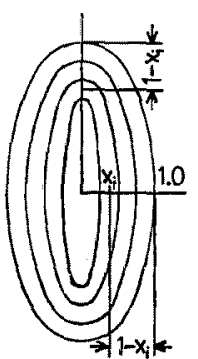

(c)
Fig. 4. Deformation modes within a spherulite. (Draw direction vertical)

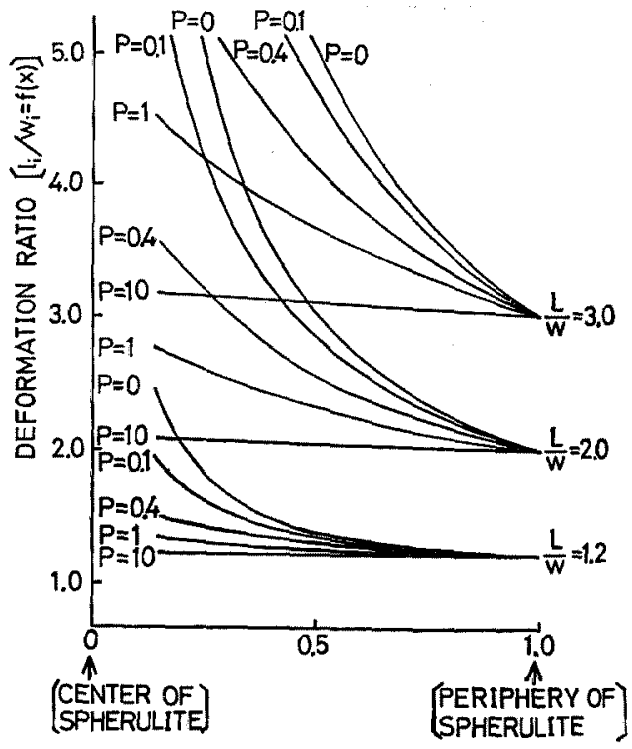

Fig. 5. Relations between the parameter and the deformation ratio shown in equation (1). 
相似型変形となる。

(1)式汇括いて球晶外形の変形比 $(L / W)$ と $P$ が変わ るとき球晶内の変形比 $\left(l_{i} / w_{i}\right)$ がどのよらに変化するの か計算した結果をFig. 5 亿示してあり，球晶最外殸の变 形比が一定でもPの值により球晶内の变形比は著しく異 なる。実測した $l_{t} / w_{i}$ の $x$ に対する曲線によく合致する
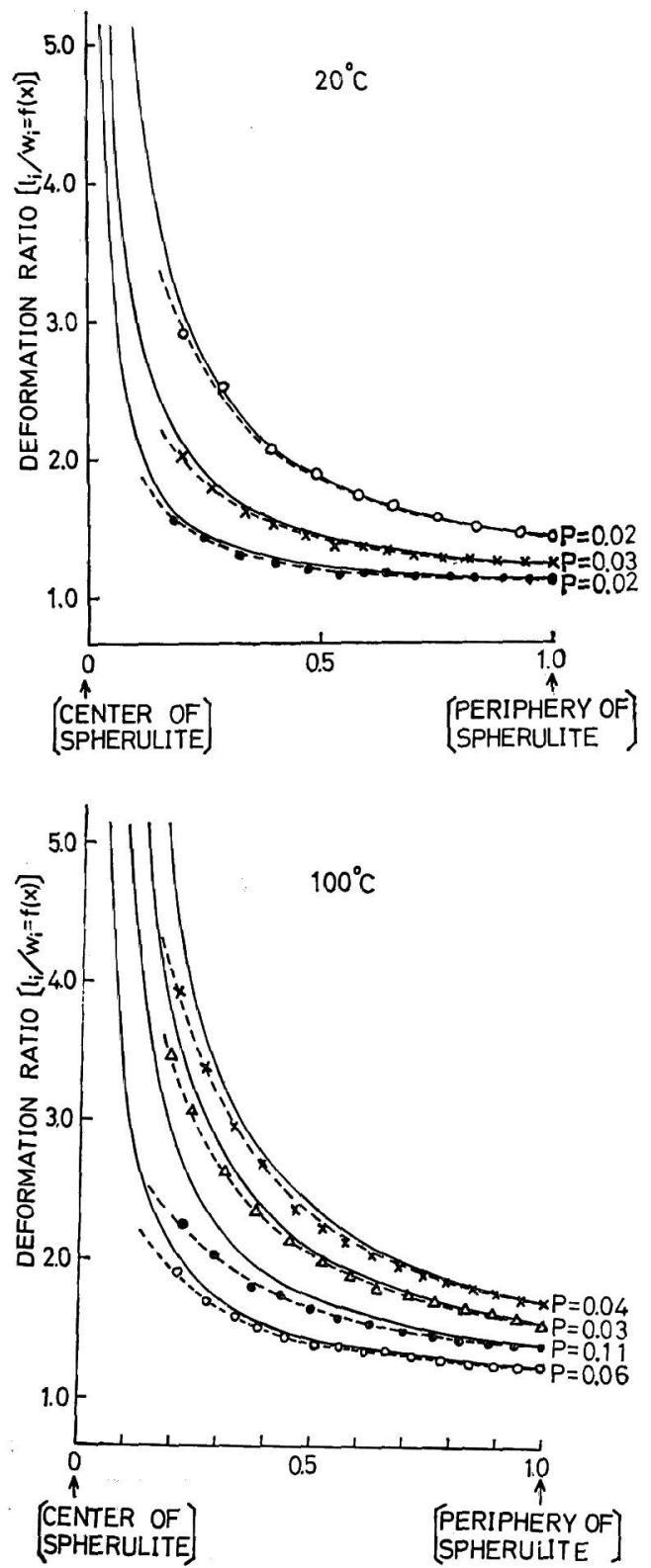

Fig. 6. Relations of the deformation ratio between periphery and inner of spherulite. Drawn two-dimensional spherulite at $20^{\circ} \mathrm{C}$ and $100^{\circ} \mathrm{C}$.
曲線を与えるよらな $P$ の値を図上で求めると，この $P$ の 值より変形が相似型であるか多重殸型であるかる評価す ることができる。このPの値の変化は，球晶内の何らか の物理量と直接対応できるといらょうな值ではないが， ポリエチレンの変形様式が多重殼型か相似型か，または その中間であるかを形式的にあらわするので，これによ りたとえば延伸による变形椂式の変化の過程を把握でき る。

\section{$3 \cdot 3$ 球晶外形の変形比と球晶内部の变形比}

\section{$3 \cdot 3 \cdot 12$ 次元球晶}

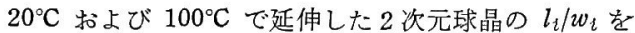
xに対してプロットしたのが Fig. 6 である。実測值によ く合致する曲線（点線）を与兄る $P$ の値を求めた。実線 は球晶最外殼の $L / W$ が実測值と同じ值にしたときの $P=0$ の曲線である。Pの値は延伸比によらず小さい值 となって扣り，変形が多重殼型に近い変形榚式にしたが
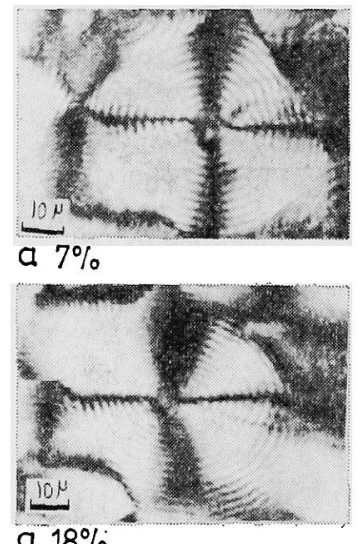

a $18 \%$
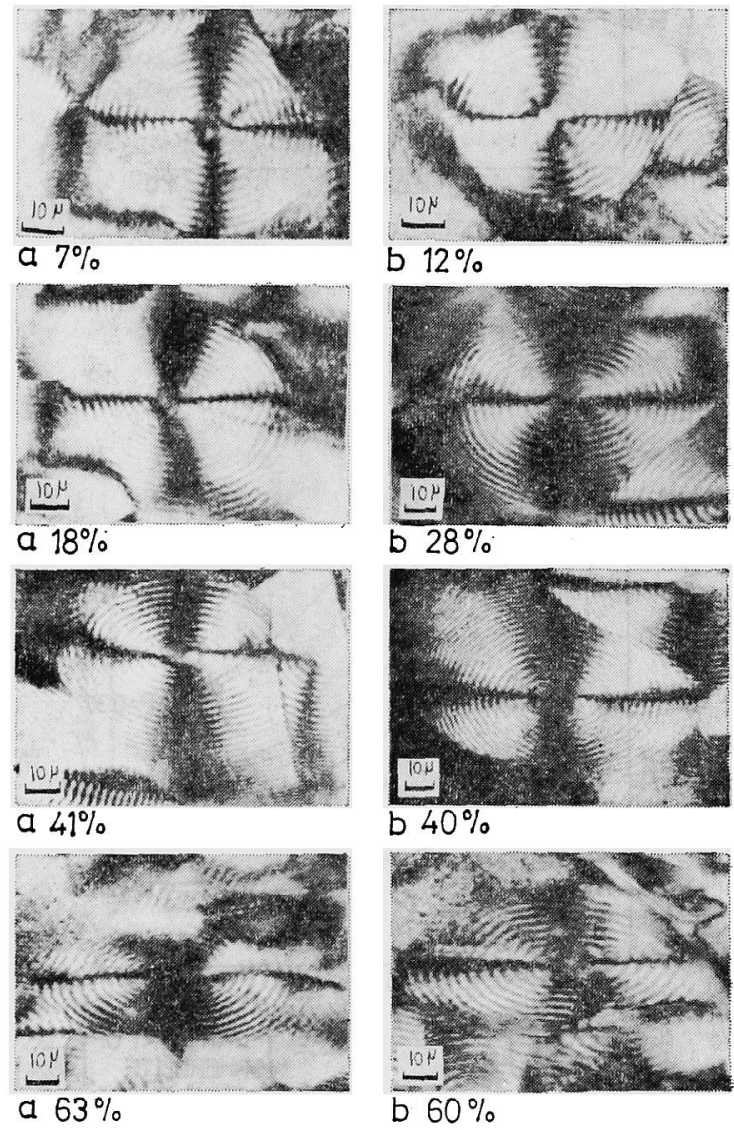

Fig. 7. Optical micrographs of drawn three-dimensional spherulite. $a$ and $b$ were drawn at 20 ${ }^{\circ} \mathrm{C}$ and $100^{\circ} \mathrm{C}$. (Draw direction horizontal) 
っていることか゚わかる。これはラメラの半経方向の周期 的よじれ構造，すなわら環状構造がよく登達して如り， 変形によってもこの權造が維持される傾向の強いことを 示している。内款部が外殸部よりも变形率が大であるの

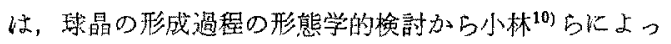
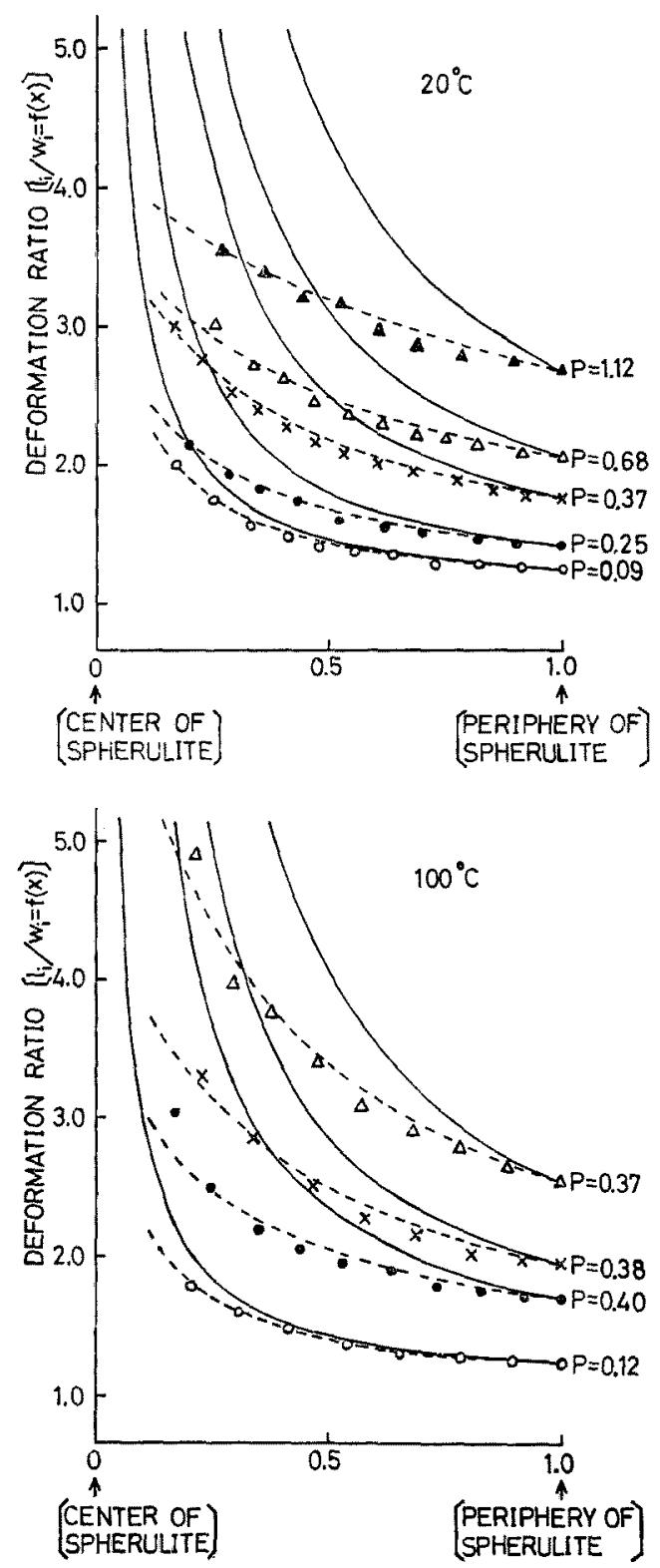

Fig. 8. Relations of the deformation ratio between periphery and inner of spherulite. Drawn three-dimensional spherulite at 20 ${ }^{\circ} \mathrm{C}$ and $100^{\circ} \mathrm{C}$.
て指摘されているよらに，球晶中心部は構造が粗であり 応力集中を受けやすい領域であるためと考えられる。 メラのよじれ周期の間隔に変化がすたらされなければな らない相似型の变形椂式伤行する以前に，球晶は内部 においてネッキングを起こし破壊されてしまら。

\section{$3 \cdot 3 \cdot 2 \quad 3$ 次元球晶}

延伸した 3 次元球晶の偏光影微鏡写真を Fig.7亿示 す，\%以球晶最外凯の变形比から，球晶加体積一定で变 形したとして，計算した值である。このような3次元球 晶について変形比を

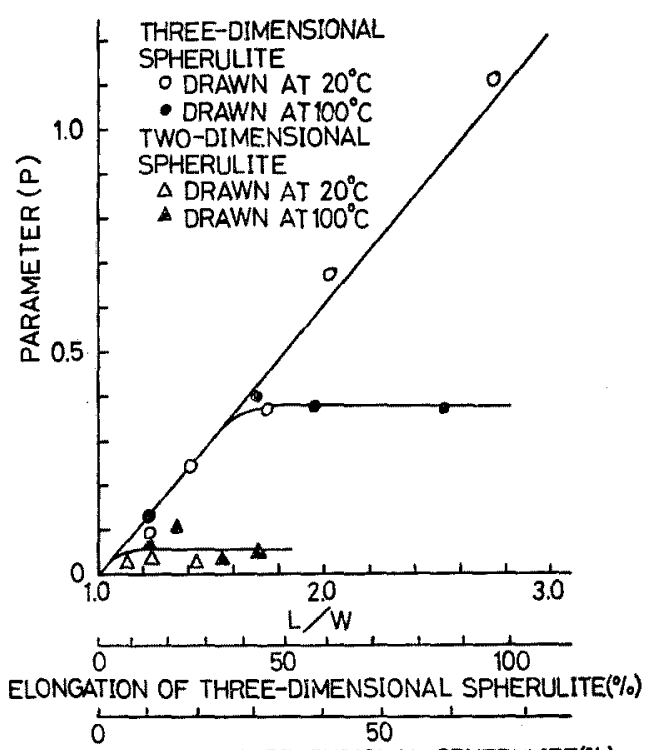

ELONGATION OF TWO-DIMENSIONAL SPHERULITE $(\%)$

Fig. 9. Relations between the parameter and the deformation ratio of periphery of spherulite.

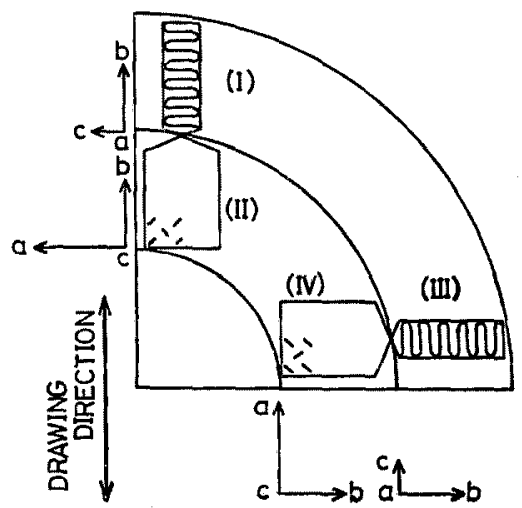

Fig. 10. Deformation mechanism of polyethylene spherulite. 
である。20 C で延伸した場合も，100年で延伸した場 合す，変形初期注多重殼型の变形様式にしたがってい るが，变形の進行とともに相似型の变形槏式との中間の 变形様式汇移行してくる。100年で延伸した場合の汪う が $20^{\circ} \mathrm{C}$ で延伸した場合よりも多重殼型の変形様式に近 いこともかかる。これは 2 次元球晶の場合と同しょうに 比較的粗な球晶中心部に応力が集中しやすいためと考克

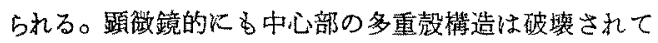
しまっでりほとんと觀察できない。

実測值に上く合政する曲線（点線）を与文るような $P$ の值を求め，こ行球晶最外殸の变形比拉よび延伸率 (L/Wより体積一定として計算した）に対してブロット したのが Fig.9である。3次元球晶を $20^{\circ} \mathrm{C} て ゙$ 延伸した 場合には，Pの值は变形比が大になるととるに連続的に 大となり，球晶の変形は変形の進行とともに相似型の変 形様式移行していくことがかかる。このとき变形の進

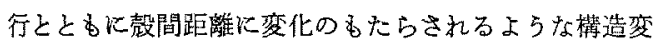
化が球晶内部で起こっていなければならない。100ㄷ で 延伸した場合，变形比の小さい間は $P$ の值が变形の進行 ととあに大沉なっていくが，その後一定の值をとってい る。したがって高温で延伸すると，球晶はある变形比以 上で绀殼問距離を維持したままの多重殸型の夜形样式に 近い変形様式にしたがっていることになる。

比較のため， 2 次元球晶についてのPの值も Fig. 9 K 示してある。Pの值は小さいらえ, 变形比と变形温度に よらず一定であることがわかる。

\section{4 变形構構}

3.3 で述べた变形様式に対椨する变形機構を検討する 必要がある。球晶の延伸軸に平行な断面の $1 / 4$ を Fig. 10 に示す。延伸方向に平行な部分と垂直な部分が，それぞ れし軸が紙面に平行な部分之垂直な部分飞分けられてい る。（I），(II)，(II)，(N) の各部分が 1 軸延伸によっ て軸配向するのに必要な結晶軸の回転と, それに対応

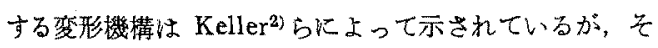
れらの中で3・3で述べたよらな変形棣式にしたがらのの た什起こりらるはずである。

ところで, ポリェチレン 3 次元球晶フィルムの $20^{\circ} \mathrm{C}$ 延伸比打配向係数恃，延伸率 $36 \%$ で $f_{c}=0.28$, $f_{a}=-0.22, f_{b}=-0.06,108 \%$ で $f_{c}=0.56, f_{a}=-0.35$, $f_{b}=-0.21,100^{\circ} \mathrm{C}$ 延伸の場合延伸率 $33 \%$ で $f_{c}=0.28$, $f_{a}=-0.02, f_{b}=-0.08,105 \%$ で $f_{c}=0.59, f_{a}=-0.40$, $f_{b}=-0.19$ です，20 $0^{\circ} \mathrm{C}$ 延伸， $100^{\circ} \mathrm{C}$ 延伸の配向保数 飞持洁る差はなかった。上炕ついて以下に述べる。

\section{$3 \cdot 4 \cdot 12$ 次元球晶}

2 次元球晶任延伸により，变形初期との殸間距離を少 し变えるが，その茄とは殻間距離をはとんど変えないで
多重竌型の変形棁式沉したがって変形する。(I)，(II)

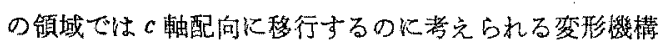
のらち、ラメラのクラッキングを伴ら $a$ 轴をるらりの $c$ 軸 の回転や，局所的ネッキングを伴ら折りたたみのとけは ぐしは殼間隔の拻大汇寄与すると考兄られ，多重殼型の 変形様式汇したが変形機構としては受け入れにくい。 したがってラメラ内に特ける分子鎖の傾斜を伴う(010) [001]スリップ，ラメラ間のすべり伴う（001）[010] スリップなどを主な变形機構と考兄るべさであるう。 (III)，(N)飞执いても分子鎖のとけ活ぐしは上と同じ理 由で考党にくく、たとえば(N)に猢るラメラのb軸ま わりの回転や， シxラ内の分子鎖の傾科伴ら (100) [001〕スリップなとが変形機構として受け入れられよう。

\section{$3 \cdot 4 \cdot 2 \quad 3$ 次元球晶}

前述の上らに 3 次元球晶の率形様式の特徽は，変形初

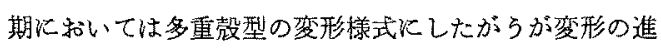
行とともに相似型の变形様式との中間的変形棣式に移行 することと，低温で延伸すると相似型の変形様式に近く なることに要的される。

变形初期では 3.4.1 で述べたよらな変形が起こってい るため，多重殼型の变形様式にしたがっていると考觉ら れる。その亦之相似型の変形様式化したがらといらこと

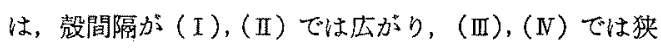
くなってくることを意味している。この場合，3.4.1 で

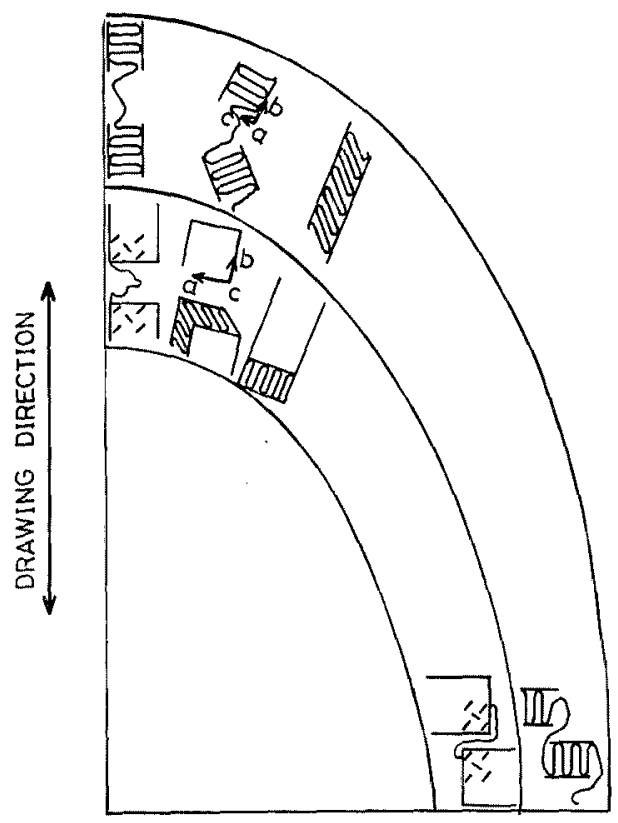

Fig.[11. Schematic representation of deformation mechanism to change thickness of an elemental shell. (Draw direction vertical) 
述へた機構に加うるに，ラメラのクラッキングや分子鎖 のと汁ほぐしが起こってくると考兄られる。(I)，(II） に詁ける䒿間隔の拡大は主に分子鎖の局所的なとけはぐ しに畺せられ上う。（且），(N)では殼間隔の狭くなる必 要があるが，これは延伸によるラネラの崩壊(クラッキ ソグ，とけ汪ぐしなと）に，延伸方向之垂植方向飞拁い て生ずる压縮力が伴って起こるるのと考えられる。非 常に単純に以上に述べた变形機满を模式化して書けば Fig.11のようになる。

低温飞称いては局所的な応力集中が起こりやすいと考 えられ，いままで述べてきたよらな局所的なネッキング が起こりやすいと考文られ，より相似型変形に近い変形 様式をとるようになると説明される。

球晶变形をモデル的に扱う場合，以上の上ら飞をれぞ れの㪍で変形率が暴なることと, 延伸温度之変形率とに

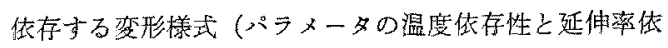
存性）のことを考虑する必要がある。

\section{5 俚縮変形による球晶の变形様式}

3次元球晶からなるポりエチレンフィルムをホットプ

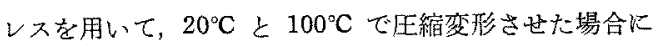
ついて同様のことを检詥した。压縮面に垂随な切片飞見 られる変形された球晶の長軸と短軸の比の实测值によく 合致する曲線を与文るP P值を求めた。Fig.12 は $P$ の 值を变形比に対してプロットしたるので方る。延伸变形 の場合と同じように低温で压縮した場合，変形の進行と ともに相似型の变形椂式に移行寸るが，高温では多重殻 型に近い変形粎式にしたがって変形することは明らかで 南る。低温で局所的応力集中の起こりやすいことは延伸 の場合と同じで妨り, ラィラのクラッキング、ラメラ内 のリポン間すべりなどが殻間距離の抎大火瓷与している と考觉られる。

\section{4. 結論}

2 次元球晶数よび 3 次元球晶からなるポリエチレンフ ィルムの变形過程を検討して次のよらな結論を得た。

(i) 3 次元球晶の球晶变形率は試料外形の変形䇾よ り小さい。これ球晶間のずれに上るものであり，低温 で延伸した場合の活らがその㑯向は大きい。

（ii）球晶の変形樣式については 2 次元球晶の場合， ほぼ多重款型の变形樣式にしたがって変形する。3 次元 球晶の場合, 变形初期に打いては多重㲄型の变形様式に 近い变形をするが，枍形の進行とともに相似型の变形様 式との中間の变形粎式に移行する。低温で延伸した場合 の汪らが相似型の变形棣式に近い。低温では局所的なネ ッキングなとが起こりやすいためと考方られる。2次元 球晶, 3 次元球晶ともに球晶内部惊と変形率は大きい。

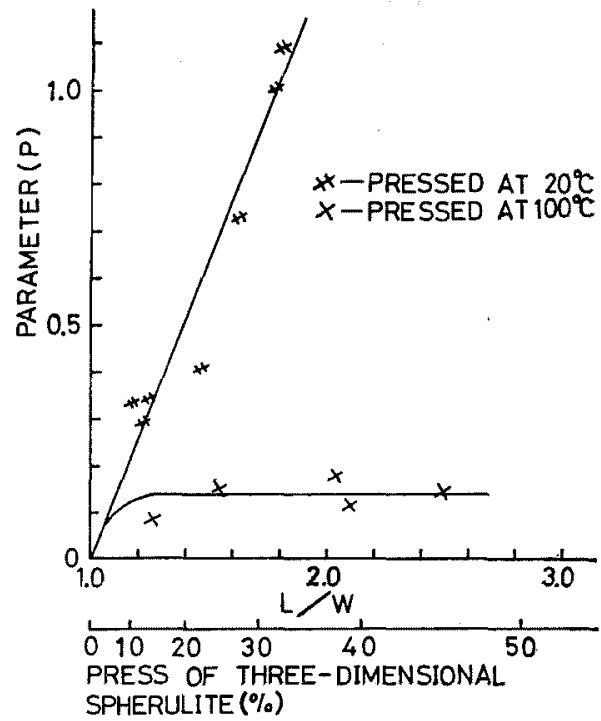

Fig. 12. Relations between the parameter and the deformation ratio of periphery of spherulite.

(iii) 多重殼型の変形様式にしたがっている間は， ま

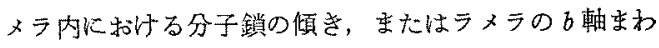
りの回軸が主な変形機楧として受け入れられる。変形の 進行につれて相似型の変形様式に移行することは, ラメ ラのクラッキングや分子鎖のとけほぼしが盛んになって くること济応している。変形様式は延伸温度, 延伸 率, 球晶の状態湾よって複雑に変化する。

（iv）圧縮による3 次元球晶の変形挙動も前述した延 伸变形の場合に類似している。主なわち変形の進行とと もに多重殻型から相似型への移行が起こり，その傾向は 低温で変形した場合注ど著しい。

付記この研究は昭和 45 年 10 月瀻維学会秋季研究発 表会（上田）に执いて発表した。

\section{文献}

1) Z. W. Wilchinsky ; Polymer, 5, 271 (1964)

2) I. L. Hay, A. Keller; Kollid-Z. Z. fur poly., 204, 43 (1965)

3) T. Oda, S. Nomura, H. Kawai ; J. Polymer Sci., A 3, 1993 (1965)

4) K. Kobayashi, T. Nagasawa ; J. Polymer Sci., C 15, 163 (1966)

5）木下茂武，馬越淳；䄉学誌，23，189（1967）

6) 高原弘和, 河合弘妯, 山田哲三; 織学誌, 23,102 (1967) : 24, 219 (1968)

7) R. Crystal, D. Hansen; J. Polymer Sci., 6, A2, 981 (1968)

8）小田隆, 坂口亘弘, 河合弘㹨; 高化, 25,588 (1968)

9）小田隆，茂木正彦，森谷雅彦，河合弘迪；高化， 25, 636 (1968)

10）小林恵之助；高分子の物性(化学同人), 207 (1664) 